\title{
Floral diversity and pollination strategies of three rheophytic Schismatoglottideae (Araceae)
}

\author{
S. L. Low ${ }^{1}$, S. Y. Wong ${ }^{1}$, I. H. Ooi ${ }^{1}$, M. Hesse ${ }^{2}$, Y. Städler ${ }^{2}$, J. Schönenberger ${ }^{2}$ \& P. C. Boyce ${ }^{3}$ \\ 1 Department of Plant Science and Environmental Ecology, Faculty of Resource Science and Technology, Universiti Malaysia Sarawak, Sarawak, Malaysia \\ 2 Department of Structural and Functional Botany, University of Vienna, Vienna, Austria \\ 3 Institute of Biodiversity and Environmental Conservation, Universiti Malaysia Sarawak, Sarawak, Malaysia
}

\author{
Keywords \\ Aridarum nicolsonii; Colocasiomyia; flowering \\ mechanism; Phymatarum borneense; \\ Schottarum sarikeense

\section{Correspondence} \\ S. Y. Wong, Department of Plant Science and \\ Environmental Ecology, Faculty of Resource \\ Science and Technology, Universiti Malaysia \\ Sarawak, 94300 Sarawak, Malaysia. \\ E-mail: sywong@frst.unimas.my

\section{Editor} \\ N. Vereecken
}

Received: 11 December 2014; Accepted: 12

February 2015

doi:10.1111/plb.12320

\begin{abstract}
Homoplastic evolution of 'unique' morphological characteristics in the Schismatoglottideae - many previously used to define genera - prompted this study to compare morphology and function in connection with pollination biology for Aridarum nicolsonii, Phymatarum borneense and Schottarum sarikeense. Aridarum nicolsonii and $P$. borneense extrude pollen through a pair of horned thecae while $S$. sarikeense sheds pollen through a pair of pores on the thecae. Floral traits of spathe constriction, presence and movement of sterile structures on the spadix, the comparable role of horned thecae and thecae pores, the presence of stamen-associated calcium oxalate packages, and the timing of odour emission are discussed in the context of their roles in pollinator management. Pollinators for all investigated species were determined to be species of Colocasiomyia (Diptera: Drosophilidae).
\end{abstract}

\section{INTRODUCTION}

Homoplastic character evolution is increasingly being detected within angiosperm clades (Givnish et al. 1999; Scharaschkin \& Doyle 2006; García et al. 2009; among others). Saether (1977) noted homoplasy within closely related clades as 'underlying synapomorphies' and described it as 'canalized evolutionary potential repeatedly producing the same apomorphic conditions.'

On Borneo, rapid species diversification in tribe Schismatoglottideae has been shown to involve homoplastic evolution within the smaller almost exclusively rheophytic genera (Wong et al. 2010; Wong 2013). Among homoplastic characters investigated, horned thecae are of particular interest not only because they are a taxonomically localised characteristic in the aroids, but also because horned thecae are used for generic delimitation, and 'pre-cladistics' delimitated 'related taxa'. Within Araceae, horned thecae are confined to two related tribes: Cryptocoryneae (Cryptocoryne Fisch. ex Wydler and Lagenandra Dalzell) and Schismatoglottideae (Aridarum M.Hotta, Bucephalandra Schott, Phymatarum M.Hotta and Schottariella P.C.Boyce \& S.Y.Wong). The prevalence of this particular homoplastic trait in these four genera of Schismatoglottideae prompted further investigation, along with attempts to understand the biological processes these mechanisms favour.

Investigation of the flowering mechanisms and pollination strategies in Schismatoglottideae is so far limited to a few recent studies (Ulrich et al. 2012; Wong \& Boyce 2013; Low et al.
2014). Boyce \& Wong (2013) and Low et al. (2014) reported the pollinators for several Aridarum and Schottarum P.C.Boyce \& S.Y.Wong species investigated were various Colocasiomyia de Meijere (Diptera: Drosophilidae), although they noted numerous incidental observations of inflorescence visitation by Sphaeridiinae and Staphylinidae (Coleoptera) to Aridarum (J. Bogner, personal communication; P. C. Boyce, personal observation; K. Nakamoto, personal communication) and Chrysomelidae (Coleoptera) to Bucephalandra, Ooia S.Y.Wong \& P.C.Boyce and Schismatoglottis Zoll. \& Moritzi (P. C. Boyce, personal observation; I. H. Ooi, personal observation). Chrysomelids are highly predatory and usually cause extensive physical damage to parts of the spadix, notably the appendix (Low et al. 2014). Several mechanisms have been observed that seem to provide protection for the inflorescence during anthesis. Among microstructures in the taxa under investigation, extracellular calcium oxalate crystals have a biotic role in inhibiting herbivory (Franceschi \& Horner 1980), but this is not necessarily true for all species investigated (Coté \& Gibernau 2012) or in enhancing pollination (D'Arcy et al. 1996).

The abundance and structural diversity of calcium oxalate crystal types in the Araceae have been investigated sporadically in taxa across the family. Most of the investigations, however, have focused on the presence of crystals in vegetative tissues (Keating 2004). D'Arcy et al. (1996) reported the presence of calcium oxalate crystals mixed with pollen in some Anthurium Schott, Calla L. and Zantedeschia Spreng. Studies have also revealed that extracellular calcium oxalate crystals are visible on the surface of the apical portion of 
nearly mature stamens of many species of Philodendron Schott (Barabé \& Lacroix 2001), in Philonotion americanum (A.M.E.Jonker \& Jonker) S.Y.Wong \& P.C.Boyce and Schismatoglottis calyptrata (Roxb.) Zoll. \& Moritzi (Barabé et al. 2004a). The types of extracellular calcium oxalate crystal differ between the epidermal surfaces, which correspond to extended aggregate/druses or crystal sand, and the oxalate crystals mixed with pollen, which correspond to raphides or styloids. The type of crystals associated with pollen varies among genera (Barabé et al. 2004b).

In this study, we report on the flowering mechanisms, pollination strategies, seed germination and seedling establishment of three rheophytic aroid taxa: Aridarum nicolsonii Bogner (Fig. 1A and B), Phymatarum borneense M.Hotta (Fig. 1E and F), and Schottarum sarikeense (Bogner \& $\mathrm{M}$. Hotta) P.C.Boyce \& S.Y.Wong (Fig. 1I and J). A. nicolsonii is endemic to and abundant in an area defined by the Sipang and Po Peninsulas, West Sarawak, Malaysian Borneo (Wong \& Boyce 2007). P. borneense is restricted to the central and northern part of Sarawak, and to Brunei (Bogner \& Hay 2000). S. sarikeense is endemic to the Kanowit-Song-Ai drainages, Sarawak, and very probably occurs into the Bentuang Karimum National Park in Kalimantan (Low et al. 2014).

While all three species are rheophytes, the last two species do not strictly adhere to the rheophytic ecological context sensu van Steenis (Wong 2013). In A. nicolsonii and P. born- eense pollen is extruded through a pair of horned thecae, while in S. sarikeense pollen extrusion occurs via a pair of pores flush with the thecae. The stamens and their microstructures together with their mechanisms and roles in the taxa were also investigated. The connection between the presence of extracellular calcium oxalate crystals and pollination mechanisms was studied. Specifically, we addressed the following questions: (i) what are the pollinators for each of these three taxa; (ii) how do the horned thecae function in extruding pollen; (iii) what is the advantage of the staminate flower calcium oxalate exudates; and (iv) how successful is the reproduction rate of these three taxa in the wild?

\section{MATERIAL AND METHODS}

\section{Study sites}

\section{Aridarum nicolsonii}

Field observations were carried out at the Type locality at Bako National Park, Sarawak, Malaysian Borneo $\left(1.43^{\circ} \mathrm{N}, 110.27^{\circ} \mathrm{E}\right.$, $250 \mathrm{~m}$ a.s.l.) between 22 and 27 November 2007 and 27 October to 3 November 2013, and at Santubong National Park, Sarawak $\left(01^{\circ} 44^{\prime} \mathrm{N}, 110^{\circ} 19^{\prime} \mathrm{E}, 120 \mathrm{~m}\right.$ a.s.l.) between 11 and 18 November 2012. At both localities A. nicolsonii grows on sandstone bedrock of partly shaded forest streams (Fig. 1A). During the rainy season most plants in the populations are
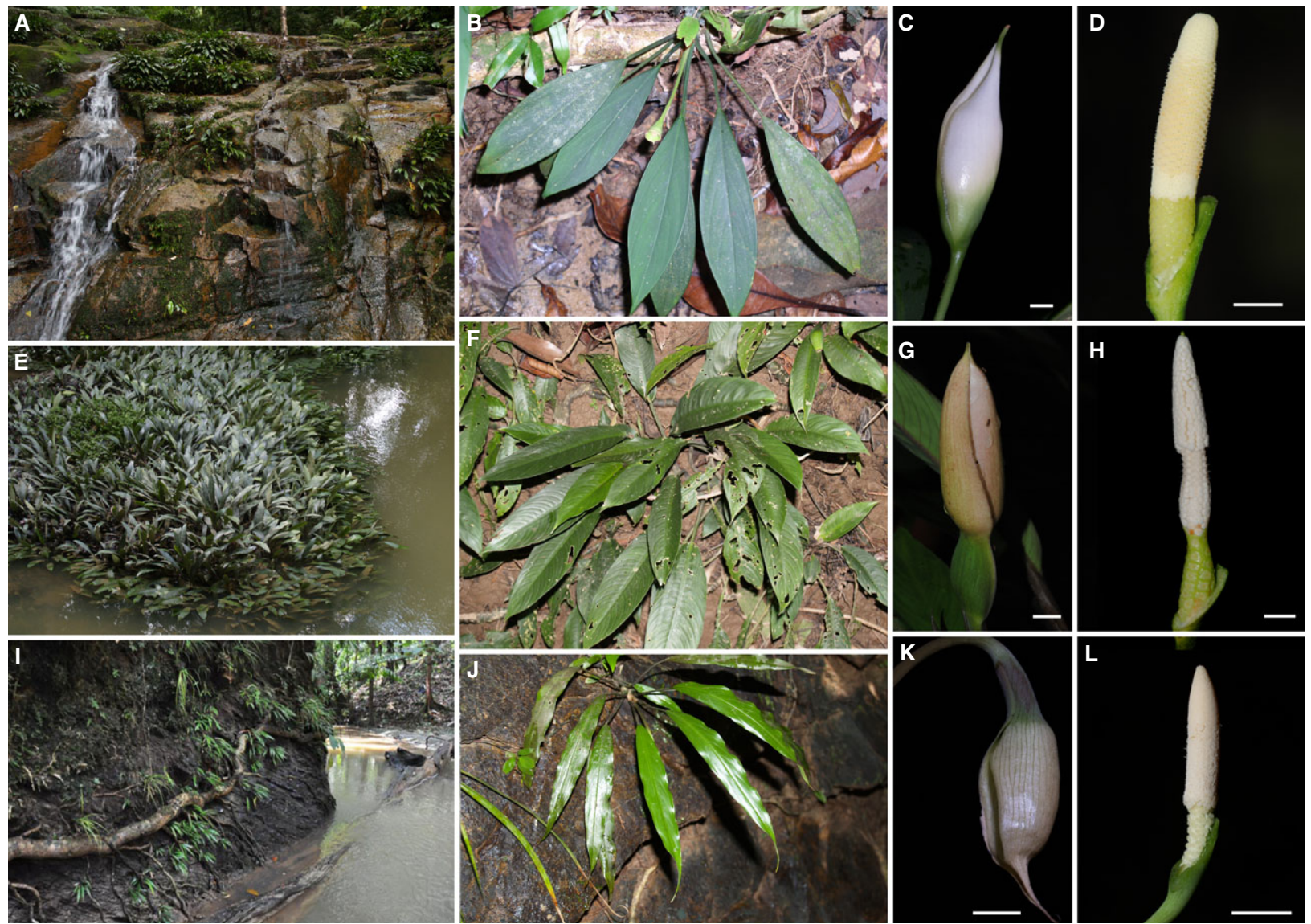

Fig. 1. Overall habitat, individual adult plants and inflorescence of Aridarum nicolsonii Bogner. A, E \& I: Plants in the wild. B, F \& J: Individual plant. C, G \& K: Inflorescence in pistillate anthesis. D, H \& L. Spathe artificially removed to reveal the spadix. Aridarum nicolsonii Bogner (A-D), Phymatarum borneense M.Hotta (E-H) and Schottarum sarikeense P.C.Boyce \& S.Y.Wong (I-L). 
immersed under torrential water. In the dry season the majority of plants will be subject to dry conditions, although with high night-time humidity. Observations were made on five inflorescences and ten infructescences.

\section{Phymatarum borneense}

Field observations were carried out at Mulu National Park, Sarawak, Malaysian Borneo, at five separate sites: three sites located along the trail to the Deer Cave $\left(c a .04^{\circ} 02^{\prime} \mathrm{N}\right.$, $114^{\circ} 49^{\prime} \mathrm{E}, 60 \mathrm{~m}$ a.s.l.) and two sites along the trail to Clearwater Cave (ca. $04^{\circ} 14^{\prime} \mathrm{N}, 114^{\circ} 53^{\prime} \mathrm{E}, 65 \mathrm{~m}$ a.s.l.). Observations were undertaken between 15 and 29 September 2009 and 2 to 10 December 2011. All sites are mostly exposed flood zones on muddy or sandy riverbanks in alluvial forest (Fig. 1E). Forty inflorescences (10 for detailed observations, 30 bagged for insect counts) and 50 infructescences were investigated.

\section{Schottarum sarikeense}

Observations were carried out between 24 January and 5 February 2010 and 5 to 10 August 2013 along the Sungai Lepong, at Sebankoi Recreational Park, Betong, Roban, Sarawak, Malaysian Borneo $\left(01^{\circ} 57^{\prime} \mathrm{N}, 111^{\circ} 31^{\prime} \mathrm{E}, 154 \mathrm{~m}\right.$ a.s.l.). S. sarikeense mostly grows on vertical mud banks within the flood zone. Thirty inflorescences (10 for detailed observations, 20 collected for insect counts) and 50 infructescences were investigated.

Peak flowering season for all three species is between August and February. The second half of this range coincides with the period of heaviest sustained rainfall.

\section{Observations on flowering mechanism, pollination strategy, seed dispersal and seedling establishment}

Observations of the flowering mechanism and pollination strategy of each species were carried out on a $24-\mathrm{h}$ basis. The onset of pistillate anthesis, the transitional stage between pistillate and staminate anthesis, staminate anthesis and any concomitant spathe movements, the function of sterile structures on the spadix and odour emission were each observed and recorded, together with their timings. Insect visitors were identified to at least family level, and their behaviours were documented. In order to determine the attractant factor for insect visitors (odour versus colour), inflorescences at the pre-anthesis stage were covered with a colour-dyed tea bag but access into the inflorescence was allowed from below.

Fruit set was defined as total fruits (berries) per infructescence divided by the total of pistillate flowers per inflorescence, and was used as a measure of the effectiveness of the pollinators. All inflorescences, infructescences and insect visitors were preserved in $70 \%$ ethanol and deposited at Sarawak Forestry Herbarium (SAR). A list of all voucher specimens is provided in Appendix S1. All images were taken using an Olympus E-300 digital camera.

\section{Microscopy and imaging work}

\section{Plant material}

Inflorescences were fixed in 70\% ethanol. Microscopy and imaging work was carried out at the Palynology Laboratory, Department of Structural and Functional Botany, University of Vienna, Vienna, Austria.

\section{Scanning electron microscopy (SEM)}

Staminate flowers were fixed in 70\% ethanol and partially dissected under a stereomicroscope. Specimens were dehydrated in a graded ethanol series to absolute ethanol, and preserved in pure acetone. The specimens were then dried in a critical point drier (Autosamdri-815), using $\mathrm{CO}_{2}$ as a transitional medium, mounted on metal stubs, and sputter-coated with gold. Specimens were viewed under a JEOL JSM-6390 SEM (JEOL, Peabody, MA, USA) with digital imaging capacity at $10 \mathrm{kV}$.

\section{$X$-ray tomography}

Staminate flowers were infiltrated in 1\% phosphotungstic acid in $70 \%$ ethanol for 2 weeks in order to increase contrast (Staedler et al. 2013). Specimens were then transferred into a $200-\mu 1$ pipette tip and topped with the same buffer. The specimens were then scanned using an XRadia XCT-200 (Pleasonton, CA, USA); scanning conditions are summarised in Table S1.

\section{RESULTS}

\section{Aridarum nicolsonii}

\section{Reproductive stages and pollination strategies}

Aridarum nicolsonii produces a single inflorescence requiring up to 6 weeks to reach maturity from the time they are determinable as inflorescences. During development the peduncle grows at $4 \mathrm{~mm} \mathrm{day}{ }^{-1}$, reaching a maximum length of $18 \mathrm{~cm}$. The spathe grows at $1.6 \mathrm{~mm} \mathrm{day}^{-1}$, to a maximum length of $7 \mathrm{~cm}$. A mature inflorescence is held in an erect position relative to the arching petioles, with the spathe at pistillate anthesis more or less broadly ovate, not constricted, but clearly differentiated into a lower spathe and a spathe limb (Fig. 1C). The spathe limb is caducous about 3 days after anthesis (Fig. 2D) or exceptionally (possibly under dry conditions) remains and becomes marcescent. The spadix comprises (from base) a row of staminodes located along the spathe/spadix adnation, a cylindrical pistillate zone with crowded pistils, averaging $107 \pm 19$ per spadix (Table 1), with globose ovaries and a sessile, discoid, centrally-impressed stigma, that is barely papillate at pistillate anthesis. Above the pistillate zone, a sterile interstice is present that comprises about six irregular whorls of truncate, centrally impressed, circular (plane view) staminodes. The staminate zone comprises crowded stamens arranged for the most part in longitudinally aligned pairs. The connectives are excavated with a pair of short sub-erect horned thecae on the distal and proximal sides. The spadix is terminated with an appendix, comprising irregularly polygonal to more or less circular (plane view) staminodes (Fig. 1D).

Anthesis of $A$. nicolsonii lasted 29 h. Pistillate anthesis started at $06: 00 \mathrm{~h}$ (local time, UTC $+8: 00$ ) with a gap (3-mm wide) formed at the tip of the spathe limb and extended along the spathe margin by 07:00 h (Fig. 2A). The spathe inflated, thereby allowing access into the pistillate zone containing the now receptive pistils. An acetic acid-like odour was detected and suspected to originate from the appendix and, at the same time, a second fruity odour was released from the pistillate zone. The acetic acid-like odour reduced at 11:00 h but the fruity smell persisted throughout the pistillate anthesis. The pistillate zone was covered with mucilage by 16:30 h. The previous odours were no longer detected but a third odour, 

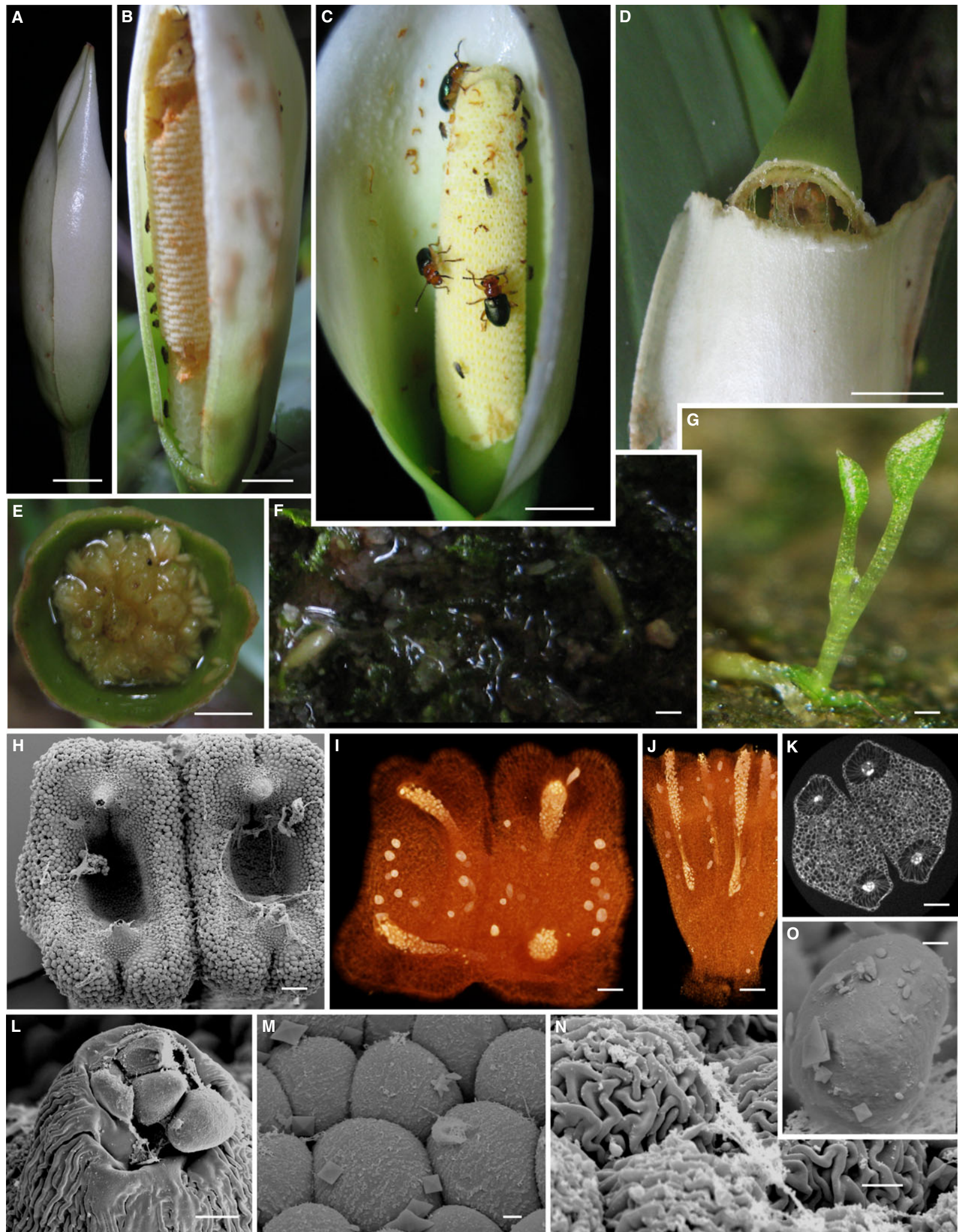

Fig. 2. Flowering mechanism, pollinators and insect visitors, seed dispersal, seedling establishment and stamen, together with its microstructures in Aridarum nicolsonii Bogner. A: Inflorescence at the onset of pistillate anthesis. B: Spathe artificially removed to reveal the spadix during pistillate anthesis; note the presence of Colocasiomyia. C: Inflorescence at the onset of staminate anthesis. Not the presence of Chaloenus. D: Spathe abscission at post anthesis. E: Seeds ready to be dispersed. F: Seeds on the moss surface. G: Seedling. H-K: Two stamens, each with two thecae horns and an excavated connective. I: Note the pollen and calcium oxalate packages. J: Thecae paths. K: Endothecial cells surrounding the thecae paths. L: Pollen at the tip of horned theca. M: Calcium oxalate. $\mathrm{N}$ : Vermiform cells at the base of horned thecae. O: Pollen. Scale bar: $1 \mathrm{~cm}(\mathrm{~A}-\mathrm{D}), 10 \mathrm{~mm}(\mathrm{E}-\mathrm{G}), 100 \mu \mathrm{m}(\mathrm{H}-\mathrm{I}), 50 \mu \mathrm{m}(\mathrm{J}), 100 \mu \mathrm{m}(\mathrm{L}), 5 \mu \mathrm{m}(\mathrm{M}-\mathrm{O})$ 
Table 1. Number of pistillate flowers and of fruits, percentage fruit set and seed dispersal distance of Aridarum nicolsonii, Phymatarum borneense and Schottarum sar$i k e e n s e$. (For counting of pistillate flowers, ten inflorescences were used for each species; for fruit set, $n=10$ for $A$. nicolsonii, $\mathrm{n}=50$ for $P$. borneense and $S$. sarikeense).

\begin{tabular}{llll}
\hline mean number \pm SD & Aridarum nicolsonii & Phymatarum borneense & Schottarum sarikeense \\
\hline pistillate flowers & $107 \pm 19$ & $49 \pm 8$ & $52 \pm 7$ \\
fruits & $102 \pm 13$ & $46 \pm 7$ & $47 \pm 8$ \\
$\%$ fruit set & 95.5 & 93.9 & 92.0 \\
seed dispersal & $26.2 \pm 19.3$ & - & - \\
distance (m) & & & \\
\hline
\end{tabular}

fermented fruit smell, was detected in the spathe limb chamber (probably from the interstice staminodes or the staminate zone). These changes indicated the transitional period from pistillate anthesis to staminate anthesis. The gap into the pistillate zone persisted (Fig. 2B). The spathe limb was widely expanded by the second morning, 05:00 h (Fig. 2C). The fermented fruity smell intensified and thecae horns became semierect. Between 05:00 and 06:00 h, liquid droplets were extruded (possibly containing pollen) and were then followed by pollen strings.

Two types of insect visitor were attracted to the inflorescences of A. nicolsonii (Table 2), Colocasiomyia and Chaloenus. Species of Colocasiomyia and Chaloenus accounted for $56.8 \%$ and $43.2 \%$ of total insects, and were present throughout anthesis. Four species have been collected: Colocasiomyia sp. 8 aff. bogneri (Diptera: Drosophilidae; Fig. 2B; ca. 1.5-mm long 9 0.5$\mathrm{mm}$ wide) and Colocasiomyia sp. 30 aff. bogneri (only one individual found and identified), Chaloenus sp. $1 \mathrm{nr}$. brooksi (Coleoptera: Chrysomelidae) and Chaloenus sp. 3 nr. brooksi (Fig. 2C; both species are ca. 6-mm long $93-\mathrm{mm}$ wide). Colocasiomyia sp. 8 aff. bogneri arrived through the gap formed along the spathe margin. During pistillate anthesis, this species was mostly found in but not restricted to the pistillate zone. Chaloenus sp. $1 \mathrm{nr}$. brooksi and Chaloenus sp. 3 nr. brooksi are larger than the gap between the lower spathe and the pistillate zone, and were restricted to the upper spadix. On post pistillate anthesis, all insects shifted to the upper spadix, but as the spathe opened wide, access to the pistillate zone was no longer restricted. Colocasiomyia sp. 8 aff. bogneri were observed to consume secretions from the excavated stamens. Chaloenus consumed the interstice and appendix staminodes, spathes and occasionally the staminate tissues as well. Colocasiomyia sp. 8 aff. bogneri left the inflorescence from 11:00 h (day 2) onwards, while several Chaloenus remained to consume the tissue organs. Anthesis ended at this time.

Infructescence development from the end of anthesis until seed dispersal lasted for 60 days. Fruit set of A. nicolsonii was high (95.5\%; Table 1). Fruits deliquesced when ripe to reveal the seeds (Fig. 2E). Seeds were washed out from the fruiting spathe by raindrops or water flow from the stream, and either lodged on moss near the mother plant or sometimes dispersed further into the stream, with an average of $26.2 \mathrm{~m}$ dispersal distance (Table 1). The micropylar appendages of seeds split to assist anchorage (Fig. 2F). The seeds germinated within 2 days on moss (Fig. 2G) but were never seen to germinate on bare rock surfaces. Mucilage was detected at the tip of the root of young seedlings and adult plants to help provide anchorage.

\section{Staminate flower and its microstructures}

A staminate flower of $A$. nicolsonii comprises two stamens; each stamen has two horned thecae opposite each other, at distal and proximal sides (Fig. $2 \mathrm{H}$ ), and separated by a deeply excavated connective. The three-dimensional (3-D) images showed that the four horned thecae of $A$. nicolsonii developed independently (Fig. 2I and J). The theca is elliptic and approximately two-thirds the length of the stamen. The stamen surface from near the base of the horned thecae to the sides of the excavated connective is covered with worm-like (vermiform) cells (Fig. 2L and N), but the cells on the floor of the excavation are smooth (Fig. 2M). Transverse sections of the stamens showed that endothecial cells (micrograph not shown) were present at $120 \mu \mathrm{m}$ from the tip of the thecae horn but absent from the inner side (closest to excavated connective). However, the endothecial cells began to develop around and along the theca path below the excavated connective (Fig. 2K). Pollen and oxalate crystals were observed within thecae paths (Fig. 2I$\mathrm{K}$ ) and at the tip of the horned thecae (Fig. 2L). Pollen of $A$. $n i$ colsonii is $20 \mu \mathrm{m}$, ovoid, inaperturate and psilate (Fig. 2O). Idioblasts (containing calcium oxalate crystals) and tannin cells were also found on epidermal tissues (Fig. 2I, J and M). A video from a 3-D model generated from X-ray tomography scanning data is available (Video S1) to view the stamen in three dimensions.

\section{Phymatarum borneense}

\section{Reproductive stages and pollination strategies}

Phymatarum borneense produces up to four inflorescences in sequence per flowering module. Each inflorescence is carried on an erect peduncle and the spathe is separated by a constriction into a lower spathe and spathe limb (Fig. 1G). The spathe limb is caducous as early as the onset of staminate anthesis. The spadix comprises (from base) scattered pistillodes along the spathe/spadix adnation, a conoid to sub-cylindrical pistillate zone with crowded pistils, averaging $49 \pm 8$ per spadix (Table 1), with strongly depressed-globose ovaries and a sessile discoid stigma that is papillate. Above the pistillate zone, is a sterile interstice comprising irregularly rounded-rectangular, somewhat impressed centrally, densely papillate staminodes. The latter occasionally bear vestigial horns. The staminate zone is short and slightly narrower than the interstice and comprises large, rounded-rectangular, apically densely tubercular-papillate centrally somewhat impressed stamens. The thecae are paired on the proximal (with respect to spadix axis) side of the stamen, with slender, spreading and distally sharply up-turned (lower part of staminate zone) and down-turned (upper part of staminate zone) horns. The terminal appendix is elongateconoid and bears staminodes (Fig. 1H).

Anthesis lasted for $26 \mathrm{~h}$. Pistillate anthesis began at 04:30 h with the spathe limb inflating and two gaps (each 1-mm wide) forming; one on the spathe limb, near the tip, and another at the constriction between the spathe limb and the lower spathe. These spathe movements coincided with the production of a mild esteric odour. The gaps extended along the spathe margin 
Table 2. Insect visitors found in the inflorescences of Aridarum nicolsonii, Phymatarum borneense and Schottarum sarikeense ( $F=$ female insects; $M=$ male insects; insect individuals per inflorescence, $\mathrm{N}=5$ for $A$. nicolsonii, $\mathrm{N}=30$ for $P$. borneense, $\mathrm{N}=20$ for $S$. sarikeense).

\begin{tabular}{|c|c|c|c|c|c|c|}
\hline & $\begin{array}{l}\text { Aridarum } \\
\text { nicolsonii }\end{array}$ & total & $\begin{array}{l}\text { Phymatarum } \\
\text { borneense }\end{array}$ & total & $\begin{array}{l}\text { Schottarum } \\
\text { sarikeense }\end{array}$ & total \\
\hline \multirow[t]{8}{*}{ Colocasiomyia } & $1-8$ individuals & 21 individuals & 2-54 individuals & $\begin{array}{l}787 \text { individuals (only } 680 \\
\text { individuals were identified) }\end{array}$ & $1-21$ individuals & $\begin{array}{l}149 \text { individuals } \\
\text { (only } 39 \text { individuals } \\
\text { were identified) }\end{array}$ \\
\hline & two species: & & six species: & & Three species: & \\
\hline & $\begin{array}{l}\text { C. sp. } 8 \text { aff. } \\
\text { bogneri }\end{array}$ & $\begin{array}{l}\text { F- } 8 \text { individuals; } \\
\text { M- } 12 \text { individuals }\end{array}$ & C. sp. 4 aff. bogneri & $\begin{array}{l}\text { F- } 68 \text { individuals; } \\
\text { M- } 63 \text { individuals }\end{array}$ & C. sp. 8 aff. bogneri & $\begin{array}{l}\text { F- } 1 \text { individual; } \\
\text { M- } 4 \text { individuals }\end{array}$ \\
\hline & $\begin{array}{l}\text { C. sp. } 30 \text { aff. } \\
\text { bogneri }\end{array}$ & M- 1 individual & C. sp. 6 aff. bogneri & $\begin{array}{l}\text { F- } 4 \text { individuals; } \\
\text { M- } 7 \text { individuals }\end{array}$ & C. sp. 10 aff. bogneri & $\begin{array}{l}\text { F- } 1 \text { individual; } \\
\text { M- } 2 \text { individuals }\end{array}$ \\
\hline & & & C. sp. 7 aff. bogneri & $\begin{array}{l}\text { F- } 6 \text { individuals; } \\
\text { M- } 5 \text { individuals }\end{array}$ & C. sp. 30 aff. bogneri & $\begin{array}{l}\text { F- } 8 \text { individuals; } \\
\text { M- } 23 \text { individuals }\end{array}$ \\
\hline & & & C. sp. 8 aff. bogneri & $\begin{array}{l}\text { F- } 238 \text { individuals; } \\
\text { M- } 270 \text { individuals }\end{array}$ & & \\
\hline & & & C. sp. 11 aff. bogneri & M- 3 individuals & & \\
\hline & & & C. sp. 29 aff. bogneri & $\begin{array}{l}\text { F- } 8 \text { individuals; } \\
\text { M- } 8 \text { individuals }\end{array}$ & & \\
\hline \multirow[t]{7}{*}{ Chaloenus } & 0-9 individuals & $\begin{array}{l}16 \text { individuals } \\
\text { (Only } 5 \text { were } \\
\text { identified) }\end{array}$ & 0-14 individuals & 53 individuals & $0-4$ individuals & 20 inviduals \\
\hline & two species: & & three species: & & five species: & \\
\hline & C. schawalleri & 1 individual & C. dohertyi & 51 individuals & C. schawalleri & 1 individual \\
\hline & C. sp. 1 nr. brooksi & 2 individuals & $\begin{array}{l}\text { C. sp. } 1 \text { nr. brooksi } \\
\text { (Only found once) }\end{array}$ & 1 individual & $\begin{array}{l}\text { C. schawalleri } \\
\text { (pale type) }\end{array}$ & 2 individuals \\
\hline & C. sp. 3 nr. brooksi & 2 individuals & Acrocrypta sp. & 1 individual & C. sp. 3 nr. brooksi & 1 individual \\
\hline & & & & & C. sp. 2 nr. permai & 7 individuals \\
\hline & & & & & C. sp. 5 near sp. 2. & 9 individuals \\
\hline Altica cyanae & - & & - & & $0-1$ individual & \\
\hline Cycreon & - & & 0-7 individuals & & $0-2$ individuals & \\
\hline
\end{tabular}

and coalesced within $10 \mathrm{~min}$ (Fig. 3A). At 05:00 h the spathe limb inflated to a maximum of $2-\mathrm{cm}$ wide, with the gap widening to $1-\mathrm{cm}$, thereby enabling the spadix to be seen. By 08:00 $\mathrm{h}$ the spathe limb gap had reduced to $5-\mathrm{mm}$ wide (Fig. $3 \mathrm{C}$ ), a stronger esteric-like odour was released from the appendix, and the stigmas were receptive (as indicated by the presence of large stigmatic droplets; Fig. 3B). The spathe remained in this state for the next $24 \mathrm{~h}$. Throughout the pistillate anthesis, a gap $1-\mathrm{mm}$ wide existed between the sterile interstice of the spadix and the inner wall of the spathe constriction. At 10:00 h, the constriction zone of the spathe tightened and closed by coming in contact with the staminodes at the interstice (Fig. 3C). This marked the transitional stage from pistillate to staminate anthesis. The odour, however, persisted during this stage.

On the second day at 03:00 h, staminate anthesis began with the spathe limb opening wide within $1 \mathrm{~h}$, recurving and partially abscising from its junction with the persistent lower spathe, which remained on the inflorescence (within $2 \mathrm{~h}$; Fig. $3 \mathrm{G}$ and E). Droplets (possibly containing pollen) were extruded from the tip of the horned thecae, which were followed by pollen strings. Pollen remained visible for the next $24 \mathrm{~h}$ (Fig. 3H). At this stage, a mild esteric-like odour was still detected.

Three types of insect visitor were found in the inflorescences of P. borneense, Colocasiomyia, chrysomelids and Cycreon Orchymont (Coleoptera: Shaeridiinae: Megasternini). Colocasiomyia were present in all of the observed inflorescences, with the number of individuals ranging from 2 to 54 per inflo- rescence ( $87.8 \%$ of total insect visitors; Fig. $3 \mathrm{~A}$ and $\mathrm{G}$, Table 2 ). Six species of Colocasiomyia have been identified: Colocasiomyia sp. 4 aff. bogneri, C. sp. 6 aff. bogneri, C. sp. 7 aff. bogneri, C. sp. 8 aff. bogneri, C. sp. 11 aff. bogneri and C. sp. 29 aff. bogneri. Chaloenus dohertyi (Coleoptera: Chrysomelidae; Fig. 3D), Chaloenus sp. 1 nr. brooksi and Acrocrypta sp. were found each in a single inflorescence. Total individuals of Chaloenus per inflorescence ranged from zero to14 (6.8\%; Table 2). A hydrophilid genus, Cycreon (Fig. 3A), was occasionally found in inflorescences, with zero to seven (5.4\%) per inflorescence.

At the onset of pistillate anthesis, Colocasiomyia arrived and entered via the spathe limb gap, into the pistillate zone, interstice or/and appendix, but never alighted on the staminate zone. The gap between the sterile interstice of the spadix and the inner wall of the spathe constriction permitted only species of Colocasiomyia $1.5-\mathrm{mm}$ long $\times 0.5-\mathrm{mm}$ wide access to the pistillate zone held within the lower spathe. Chaloenus dohertyi (6-7-mm long $\times 3-4-\mathrm{mm}$ wide) were present during and after anthesis. The insects entered the inflorescence via the gap or sometimes by chewing through the tip of the spathe. The beetles fed mainly on the appendix, sometimes on staminodes at the base and interstice, but rarely on the staminate zone and inner wall of the spathe limb. These beetles were aggressive and engaged in fights to dislodge other beetles of the same species from the inflorescence. Cycreon (2.0-mm long $\times 1.5-\mathrm{mm}$ wide) entered the inflorescences via gaps from the onset of pistillate anthesis until late pistillate anthesis. Although the size of $\mathrm{Cycr}$ eon is small enough to enter the lower chamber, Cycreon 


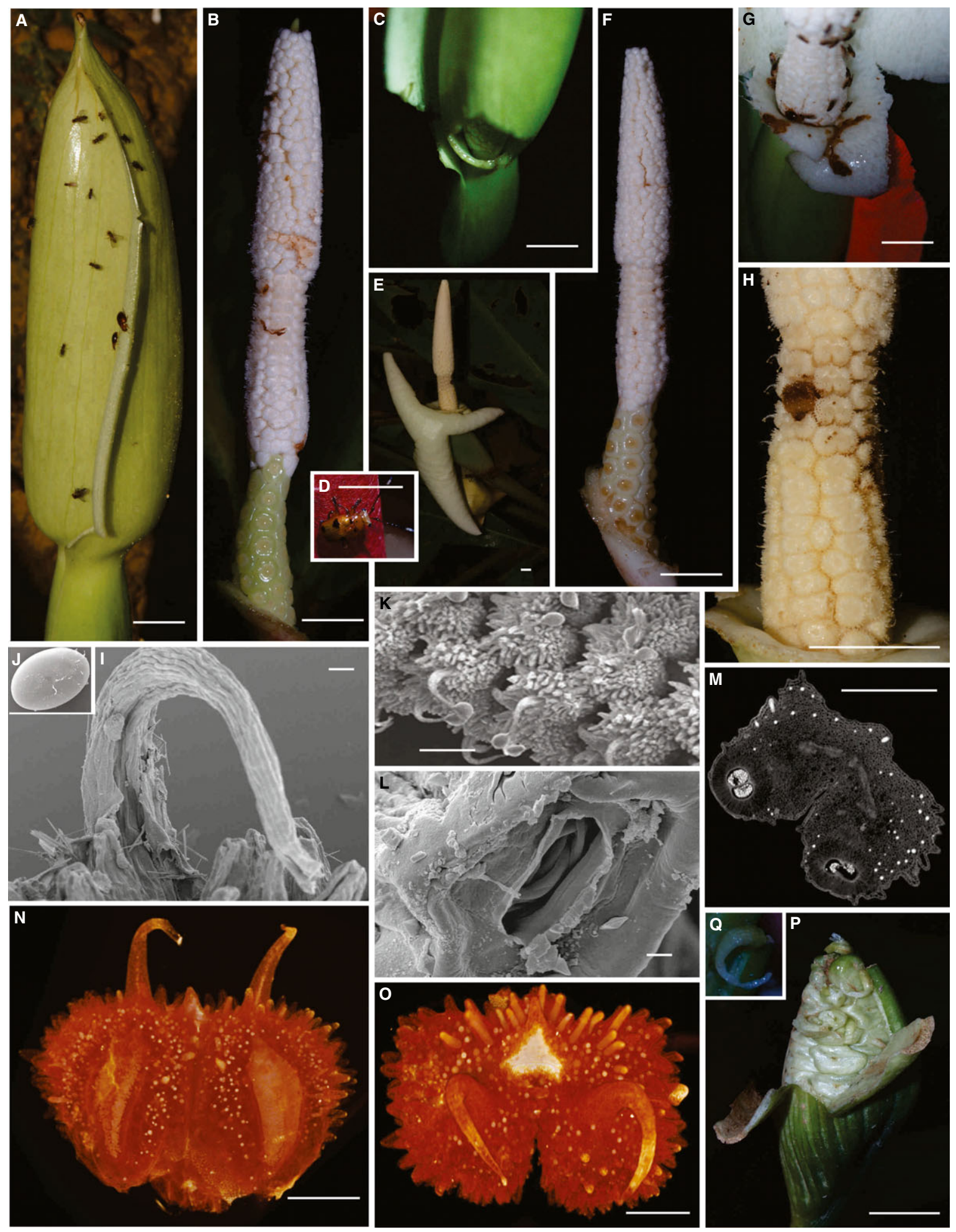

Fig. 3. Flowering mechanism, pollinators and insect visitors, seed dispersal, seedling establishment and stamen, together with its microstructures in Phymatarum borneense M. Hotta. A: Inflorescence at the onset of pistillate anthesis. B: Spathe artificially removed to reveal the spadix at pistillate anthesis. C: The gap between the spathe constriction and interstice at pistillate anthesis. D: Chaloenus dohertyi. E: Spathe abscission at staminate anthesis. F: Spathe artificially removed to reveal the spadix at staminate anthesis. G: Access into the pistillate zone closed with the tightening of the spathe constriction. H. Staminate zone. I: Horned theca with biforines present. J: Pollen. K: Droplets accumulate at the tip of horned thecae. L: Stomata with calcium oxalate on the sides. M-O: Stamen, with pollen in the thecae paths with calcium oxalate scattered within the stamen. P: Infructescence. Q: Seed with micropylar appendage prominent. Scale bar $1 \mathrm{~cm}(\mathrm{~A}-\mathrm{H}), 1 \mathrm{~mm}(\mathrm{I}), 200 \mu \mathrm{m}(\mathrm{L}), 1 \mathrm{~mm}(\mathrm{~K}), 1 \mathrm{~mm}(\mathrm{M}-\mathrm{O}), 1 \mathrm{~cm}(\mathrm{P})$. 
remained in the upper part of the inflorescence. During the transitional stage from pistillate to staminate anthesis, all the insect visitors remained in the inflorescences, either on the interstice or on the appendix.

At the onset of staminate anthesis, Colocasiomyia moved to the staminate zone and left the inflorescence within $1 \mathrm{~h}$ after the spathe limb recurved. Colocasiomyia movements were free and unrestrained (see Video S2). At the same time, a few $C$. dohertyi and Cycreon remained on the appendix and interstice, respectively. The upper part of the spadix (excepting occasionally a row of staminodes on the interstice) degraded and abscised within 6-7 days after anthesis. The percentage fruit set was high, reaching 93.9\% (Table 1). The infructescence swelled by $160 \%$ (from 15 to $25 \mathrm{~mm}$ in diameter). The fruits developed into a green form before fading to yellowish white when fully ripe (Fig. 3P). The lower spathe liquefied to disperse the seeds into surrounding areas. The seeds sometimes germinated in the fruiting spathe before dispersal. However, the first shoot only developed within 1 month (in lab condition). Seedlings were in 'upright' position with the micropylar appendage anchored into the ground surface.

\section{Staminate flower and its microstructures}

A staminate flower of $P$. borneense comprises a single stamen (Fig. 3M). The stamen has a pair of curved horned thecae pointing upward (lower part of the staminate zone) and downward (upper part of the staminate zone). Horned thecae are individually formed, extending throughout the length of the stamen, rounded-rectangular within the inner stamen, 2-mm across (Fig. $3 \mathrm{~N}$ ). The apical portion of thecae horns are $0.8-\mathrm{mm}$ long. The surface of the stamen comprises papillate cells (clearly visible with the naked eye; Fig. $3 \mathrm{H}$ ). At the tip of each papillate cell, stomata were present (Fig. 3L). High magnification shows that the stomata comprise two guard cells; calcium oxalate crystals in the form of octahedrons and star-like crystals were also found scattered on the guard cells (Fig. 3L). Raphides in the form of biforines were found at the base and along the horned thecae (Fig. 3I); these might be extruded together with pollen. Biforines are characteristic of genera with unisexual flowers, and generally absent in bisexual flower genera (De Bary 1884; Dalitzsch 1886; Solereder \& Meyer 1928; Grayum 1984). Prior to pollen extrusion, droplets (possibly containing pollen) occurred near the tip of the completely sealed thecae horn (Fig. $3 \mathrm{~K}$ ). The pollen is ovoid, $20 \mu \mathrm{m}$, inaperturate and smooth (Fig. 3J). A video of a 3D model generated from $\mathrm{X}$-ray tomography scanning data is available (Video S3).

\section{Schottarum sarikeense}

\section{Reproductive stages and pollination strategies}

The data presented here are a combination of results from Low et al. (2014) with additional observations made for this study. S. sarikeense has a solitary inflorescence (Fig. 1K). The inflorescence is held in a nodding position and the spathe is constricted into an ovoid and slightly down-curved lower spathe (Fig. 4A) and a spathe limb, which falls fresh into circumferential rings at the onset of staminate anthesis. The spadix comprises, from its base, a row of staminodes along the spathe/ spadix adnation followed by a pistillate zone that is wholly adnate to the spathe on the dorsal side (Fig. 4B). The pistils are more or less depressed-globose, crowded, on average $52 \pm 7$
(Table 1), with discoid stigmas. Above the pistillate zone is a sterile interstice that is confined to about two irregular whorls of sterile stamens at the base of the staminate zone. This is followed by a staminate zone comprising stamens that are crowded, truncate, flat-topped, rather irregular in shape and size, ellipsoid to dumbbell-shaped from above, $0.5-\mathrm{mm}$ across and partially to completely connate into groups of two to three. The appendix comprises staminodes (Fig. 1L).

The anthesis of S. sarikeense lasts for ca $26 \mathrm{~h}$. Pistillate anthesis started around 15:00 h, when a mild esteric odour was emitted from the appendix, which lasted for the whole of pistillate and staminate anthesis. The spathe limb remained open throughout anthesis (Fig. 4C). At 21:00 h, pistillodes at the interstice expanded thereby blocking the entrance to the pistillate zone; this marked the end of pistillate anthesis for S. sarikeense (Fig. 4D). At 14:30 h on day 2, staminate anthesis started with acroscopic abscission of the still fresh spathe limb into several circumferential rings (Fig. 4E). Shortly after, a combination of powdery and long, stringy pollen was released (Fig. 4E and F). Infructescences took up to 2 months to mature. The percentage fruit set for $S$. sarikeense was as high as 92.0\% (Table 1). The mature infructescences split and reflexed to reveal ripe fruits (Fig. 4I). On the following morning, fruits were dispersed through rainfall and rising stream levels. Seeds lack a micropylar appendage.

Four types of insect visitor were found in the inflorescences of S. sarikeense: Colocasiomyia ( $80 \%$ of total), Chaloenus (13.4\% of total), Altica cyanae (Coleoptera: Chrysomelidae; $0.7 \%$ of total) and Cycreon (Coleoptera: Hydrophilidae; $6 \%$ of total; Table 2; wrongly identified as nitidulids in Low et al. 2014). Three Colocasiomyia species were identified: Colocasiomyia sp. 8 aff. bogneri, Colocasiomyia sp. 10 aff. bogneri and Colocasiomyia sp. 30 aff. bogneri. Five Chaloenus species were identified: Chaloenus schawalleri, Chaloenus schawalleri (pale type), Chaloenus sp. 3 nr. brooksi, Chaloenus sp. 2 nr. permai and Chaloenus sp. 5 near sp. 2. A gap between the spathe and interstice (1-mm diameter) allowed only Colocasiomyia (1.5-mm long $\times 0.5-\mathrm{mm}$ wide; Fig. $4 \mathrm{E}$ and F) to access the pistillate zone. The flies were observed to move freely up and down the spadix. Chaloenus (Fig. 4G), Altica cyanae (only found once; Fig. 4L) (both insects are of similar size, 6-7-mm long $\times 3-4-\mathrm{mm}$ wide) and Cycreon $(2-\mathrm{mm}$ long $\times 1.5-\mathrm{mm}$ wide; Fig. $4 \mathrm{~K}$ ) were occasionally present at the staminate zone and on the appendix during pistillate anthesis. Species of Chaloenus predated the appendix and spathe margins. Expansion of the pistillodes at the interstice blocked the entrance into the pistillate zone. Colocasiomyia shifted to the upper part of the spadix prior to closure of the lower chamber. On day 2, at 14:30 h, staminate anthesis started. Species of Chaloenus and Cycreon were covered with pollen (Fig. $4 \mathrm{~J})$. After $2 \mathrm{~h}$ of staminate anthesis, all insects left the inflorescence with pollen attached to their bodies.

\section{Staminate flower and its microstructures}

A staminate flower of S. sarikeensis comprised either two or three stamens. Each stamen consists of two thecae pores separated by a flat-topped connective. The thecae path is one-third of the length of the stamen (Fig. 4M). Each theca is connected basally to a theca of the neighbouring stamen (Fig. 4M and Q). Endothecial cells (Fig. 4P) surrounding the pores are suspected to force pollen out at the onset of staminate anthesis. Calcium 

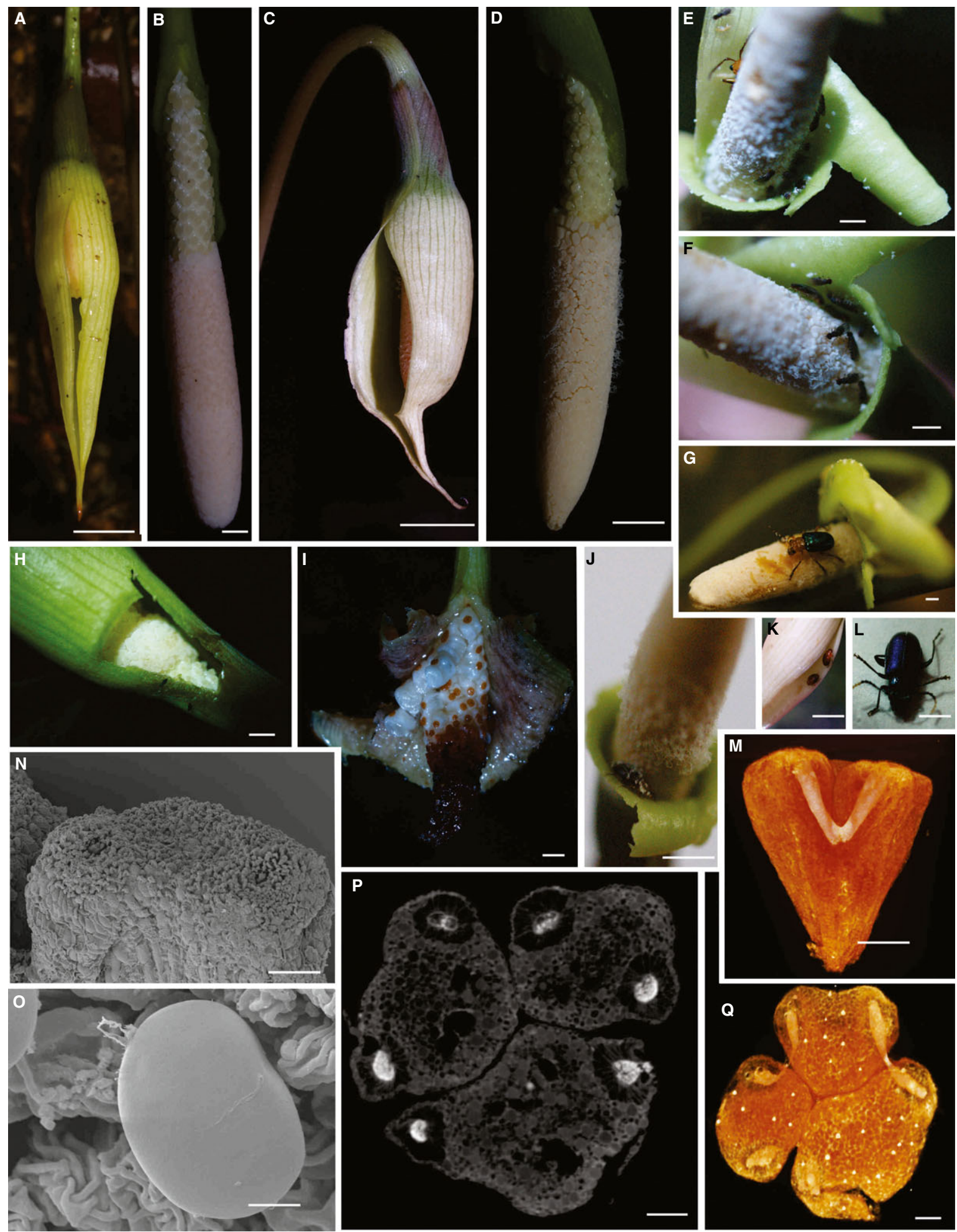

Fig. 4. Flowering mechanism, pollinators and insect visitors, seed dispersal, seedling establishment and stame, $\mathrm{n}$ together with its microstructures of Schottarum sarikeense P.C.Boyce \& S.Y.Wong. A: Inflorescence at pistillate anthesis. B: Spathe artificially removed to reveal the spadix at pistillate anthesis. C: Inflorescence at staminate anthesis. D: Spathe artificially removed to reveal the spadix at staminate anthesis. E \& F: Pollen shedding. F: Colocasiomyia present. G: Chaloenus. H: A window cut to reveal the spadix at pistillate anthesis. I: Infructescence shedding fruits. J: Cycreon covered with pollen; note the expanded pistillodes at interstice. K: Cycreon. L: Altica cynae. M-Q. Stamen. M: Thecae paths joined together. N: Thecae pores. O: Pollen. P: Endothecial cells surrounding the thecae pore. Q: Pores within the thecae paths and calcium oxalate crystals scattered within the stamens. Scale bar: $1 \mathrm{~cm}(A-D), 1 \mathrm{~mm}(E-I), 1 \mathrm{~cm}(J-K)$, $2 \mathrm{~mm}(\mathrm{~L}), 100 \mu \mathrm{m}(\mathrm{N}), 500 \mu \mathrm{m}(\mathrm{O}), 100 \mu \mathrm{m}(\mathrm{P}-\mathrm{Q})$. 
oxalate crystals (octahedrons and 3-D star-like) and tannin cells are present on the surface of the stamens (Fig. 4P and Q). The pollen is ovoid, $15 \mu \mathrm{m}$, inaperturate and smooth. A video from a 3D model generated from X-ray tomography scanning data is available (Video S4) to view the stamen in three dimensions.

\section{DISCUSSION}

\section{Flowering and main attractant}

Aridarum nicolsonii and P. borneense bloom at dawn, while S. sarikeense flowers at dusk (Table 3), uniquely so for Schismatoglottideae. The shift in flowering from dawn to dusk in $S$. sarikeense could be a reproductive isolation mechanism. In other Colocasiomyia-pollinated Araceae a shift to flowering at dusk has been observed in Colocasia affinis Schott, whereas C. esculenta (L.) Schott, C. fontanesii Schott and C. lihengiae C. L. Long \& K. M. Liu flower before dawn (Bröderbauer et al. 2014). However, C. affinis does not occur in the same clade as the other three Colocasia (Nauheimer et al. 2012). Of the several species observed in Homalomena (Homalomeneae: Araceae) on Borneo, these species, which are pollinated by scarab beetles, also flowered before dawn (Kumano \& Yamaoka 2006; Tung et al. 2010; Hoe et al. 2011). Elsewhere in the related tribe Philodendreae, which are pollinated by scarab beetles, the major events occur at dusk (Gibernau et al. 1999; Maia \& Schlindwein 2006). It seems that Schismatoglottideae and Homalomeneae tend to flower at dawn in the Old World tropics but related taxa in the Neotropics flower at dusk. This requires further investigation.

Olfactory cues were the primary means of attraction, as the release of floral odour correlates with the arrival of most insect visitors. Odour originated from the appendix (but in A. nicolsonii, more than one source of origin at different times of anthesis). Osmophoric cells in the appendix are the primary source of odour for attracting insects (Vogel \& Martens 2000; Hadacek \& Weber 2002; Miyake \& Yafuso 2003, 2005; Kakishima et al. 2011). Once the insects reached the inflorescences in the investigated three taxa, they were attracted into the lower floral chamber by a more concentrated odour (and possibly a different odour) within the pistillate zone. So far, the role of floral fragrance in mediating plant-insect interactions has only been investigated in a few species scattered across the Araceae (i.e. Patt et al. 1995; Hadacek \& Weber 2002; Kumano-Nomura \& Yamaoka 2009; Maia et al. 2010, 2012, 2013; Dötterl et al. 2012). Hadacek \& Weber (2002) reported a gradient in odour emissions in the inflorescence of Sauromatum guttatum Schott, ranging from foul-smelling in the appendix to a pleasant flowery odour at the interstice club-shaped sterile organs, and these odour compounds attracted a wide range of insects into the floral chamber. Kite (1995) showed that in the inflorescences of Arum maculatum L., the major odour-producing organ was the spadix appendix (2-heptanone, indole, p-cresol), although a different odour (germacrene B) originating from the spathe chamber was also detected.

\section{Flower visitors}

The timing of Colocasiomyia, Chaloenus and Cycreon visits corresponded to the flowering mechanisms. Colocasiomyia and Chaloenus (but not Cycreon) were attracted to the odour released, as these insects were present during the bagging test where the inflorescences were covered with netting. Cycreon, however, was absent; the occurrence of Cycreon in Araceae is reported here for the first time. It is possible that Cycreon larvae can co-exist with dipteran and nitidulid larvae in the decaying flower parts; such behaviour has been observed for staphylinid larvae in Alocasia in Australia (A. Kirejtshuk personal communication). Colocasiomyia were observed to consume the stigmatic secretions and pollen droplets (and pollen powder), and oviposit in the pistillate zone. Utilisation by Colocasiomyia of aroid inflorescences as brood sites has been reported (Miyake \& Yafuso 2003, 2005; Takenaka et al. 2006; Takenaka-Takano et al. 2012; Fartyal et al. 2013). Further investigation is needed to determine mutualistic relationships between Colocasiomyia and host plants. Colocasiomyia currently consists of about 70 species, known only to occur with Araceae, Arecaceae and Magnoliaceae (Takenaka-Takano et al. 2012). In this study, eight new Colocasiomyia species were identified (M. J. Toda personal communication). Chaloenus predate pollen and staminodes, and occasionally the inner wall of the spathe. The activity of Cycreon is not as yet clear because these insects are very sensitive to disturbance during observation.

Our results have shown that although both Colocasiomyia and Chaloenus are attracted to the odour released, it is the 'size' of insects that matters, which resulted in confinement of the Chaloenus to the upper spadix. Only species of Colocasiomyia gained access to the pistillate zone during pistillate anthesis. The stigmatic secretions may increase pollen adherence to the Colocasiomyia body parts when the insects shift to the staminate zone 24 h later. A. nicolsonii, $P$. borneense and S. sarikeense are therefore suggested here to be pollinated by species of Colocasiomyia. Fruit set failed in our living collections at Seme-

Table 3. Summary of characters of Aridarum nicolsonii, Phymatarum borneense and Schottarum sarikeense.

\begin{tabular}{|c|c|c|c|}
\hline & Aridarum nicolsonii & Phymatarum borneense & Schottarum sarikeense \\
\hline flowering time & dawn & dawn & dusk \\
\hline staminate flower & two stamens & one stamen & two-three stamens \\
\hline stamen surface & smooth, with excavated connective & verrucate, with inconspicuous connective & smooth, with flat connective \\
\hline pollen extrusion & thecae horns & thecae horns & thecae pores \\
\hline pollen & droplet and strings & droplet and strings & powder \\
\hline appendix & present & present & present \\
\hline protection post pistillate anthesis & none & constriction at spathe retightened & pistillodes at interstice expanded \\
\hline infructescence & splash cup & urceolate & urceolate \\
\hline seed & micropylar appendage & micropylar appendage & no micropylar appendage \\
\hline pollinators & Colocasiomyia & Colocasiomyia & Colocasiomyia \\
\hline
\end{tabular}


nggoh Botanical Research Centre, Kuching, surrounded by natural lowland forest. As this area lacks river systems supporting a rheophytic aroid flora, we doubt the possibility of self-pollination. Although multiple plants of several other Aridarum species (from different informal groups) flower contemporaneously in the nursery and attract a variety of insects, fruit set is very rare (Boyce \& Wong 2013). We suspect that the pollinators of many rheophytic aroids are highly localised to specific river systems. Mori \& Okada (2001) demonstrated that in populations of rheophytic Furtadoa sumatrensis M.Hotta (Araceae: Homalomeneae), also pollinated by Colocasiomyia sp., pollen flow was restricted to single river systems.

\section{A floral trap?}

Various complex spathe movements occur in all Schismatoglottideae species so far examined (Boyce \& Wong 2007; Wong \& Boyce 2010; Ulrich et al. 2012). The intricate series of events involved movement of the spathe, the phasing of fertile events, the management of pollinators, and ultimately the development and successful maturation and dispersal of fruits and seeds in Schismatoglottis and other genera of the Schismatoglottideae need further investigations (Boyce \& Wong 2007). Much needs to be done before we are in a position to attempt an overall presentation on the breadth of spathe/spadix and pollinator and dispersal interactions. All spathes of the inflorescences for the three species investigated here are inflated and partially closed except for a gap along the spathe margin at the onset of anthesis. This allows release of the floral odour to the surroundings, and at the same time, concentrates the floral odour within the inflorescence. No insect visitors are, however, confined or trapped within the inflorescences. The pollinators Colocasiomyia are not strictly restricted to the lower chamber during pistillate anthesis and are free to move within and sometimes in/out of inflorescences. The constriction at the spathe coinciding with the interstice for all three species serves as a sieve, allowing only insects of a certain size, i.e. Colocasiomyia, access to the lower chamber during pistillate anthesis. However, in Colocasia Schott, Colocasiomyia are trapped during the pistillate phase of anthesis by a narrowing of the spathe constriction, which then reopens at the end of the pistillate phase, enabling the trapped flies to access the staminate flowers (Bröderbauer et al. 2014). In Arisaema Mart. and Pinellia Ten., insects are freed from the trap by spathe movements resulting in the formation of a secondary opening (Vogel \& Martens 2000).

The constriction of the spathe in P. borneense tightened to prevent access to the lower chamber post pistillate anthesis. In S. sarikeense, the interstice pistillodes expanded to close the lower chamber. This is also observed in Bucephalandra and in species of the Aridarum Rostratum Complex, where the interstice staminodes lower and press against the inner wall of the lower spathe to seal the lower spathe chamber post pistillate anthesis (Boyce \& Wong 2013; Wong \& Boyce 2013). The role of interstice staminodes in Araceae need further investigation, not least since these structures have been reported to act as osmophoric cells (Hadacek \& Weber 2002) or/and to close access to insects after anthesis to protect the developing fruit (Mayo et al. 1997; see below for further discussion). There are other means by which the floral chamber is secluded in Araceae where, in Cryptocoryneae an extension of the spathe margin occludes the floral chamber, while in Areae a twist of the spathe causes closure of the constriction between the floral chamber and the blade (Bröderbauer et al. 2012). However, in A. nicolsonii, access to the lower chamber remained and the fruits are developed in an open splash-cup (Wong 2013). The spathe limb of all three investigated species falls off during and post staminate anthesis, and insects subsequently left the inflorescence. Pollen liberation coincides with abscission of the spathe limb in P. borneense and S. sarikeense. In A. nicolsonii, however, the spathe limb, though wide open, remains throughout staminate anthesis and is shed post anthesis.

\section{Stamens}

Staminate flowers in the three species investigated comprise one stamen (Phymatarum), two stamens (Aridarum) and occasionally three in Schottarum. Aside from Phymatarum, unistaminate flowers occur only in Bucephalandra and species of Aridarum Burtii \& Rostratum complexes (Boyce \& Wong 2013).

The stamen surface may be verrucate through the existence of papillate and sculptured cell surfaces (Phymatarum), smooth and worm-like cell surfaces (Aridarum) or smooth surfaces (Schottarum). The existence of papillate and sculptured cell surfaces is documented for the epidermis of the spathe, staminate and pistillate flowers in species of Amorphophallus Blume ex Decne, Homalomena Schott and Philodendron Schott (Mayo et al. 1997). As literature on the roles of anthers in animalpollinated flowers remains sparse (Bernhardt 1996), more work needs to be done to link the microstructure traits in a stamen to its pollination mode. Pollen of the studied species of Schismatoglottideae is ovoid, inaperturate and smooth, as reported as well by Grayum (1992).

\section{Horned thecae versus thecae pores}

In Schismatoglottideae, theca dehiscence occurs either through a pair of horns or more commonly through pores. Horned thecae are restricted to the species of four genera of Schismatoglottideae - Aridarum, Bucephalandra, Phymatarum and Schottariella (Bogner \& Hay 2000; Wong 2013). Two of these genera, Bucephalandra and Phymatarum, are unistaminate; Schottariella has paired stamens. In Aridarum, staminate flowers comprise either one or two stamens with the thecae either on the longitudinal ends or on the inner face of each anther of the stamen pair (Wong et al. 2012), or in Aridarum Burtii and Rostratum complexes, staminate flowers are unistaminate, with thecae on the proximal side of the flower (Wong et al. 2012; Boyce \& Wong 2013). Schottariella is unique in the tribe as having needle-like thecae horns emerging only at the onset of staminate anthesis (Boyce \& Wong 2008, 2009).

The nature of the thecae horns differs between $A$. nicolsonii and $P$. borneense. The horned thecae are short in A. nicolsonii but long, narrow and curved in $P$. borneense, while the thecae paths under the stamen surface are elliptic in A. nicolsonii, but round to rectangular in $P$. borneense. The pressure to extrude droplets and/or pollen may originate from within the thecae paths in A. nicolsonii, but as the thecae paths are wider in $P$. borneense, the pressure might be transferred to near the tip of the thecae horns. In P. borneense, the droplets accumulated near to the tip of the thecae horn (Fig. $3 \mathrm{~K}$ ) but the narrowed 
mid-part in the thecae paths of A. nicolsonii may produce a force to push pollen from within the thecae paths. Pollen strings of $A$. nicolsonii and S. sarikeense are extruded from thecae through contraction of endothecial cells along the theca. The thecae horns are possibly a floral trait adaptation to stream habitats, reducing pollen loss through water splashes and enabling 'active' pollen delivery according to the insect uptake. The release of pollen through horned thecae in these two taxa may have evolved to facilitate pollen deposition on the pollinator's body by increasing the levels of smearing of the pollinator body with pollen. Since pollinators may actually ignore the anthers, additional structural and physiological modifications to the anthers may have evolved to facilitate heavier pollen deposition on otherwise unresponsive forages (Bernhardt 1996). The structure and mechanism of the horned thecae varies between these two taxa. The results confirm that the thecae horns are independently derived among the taxa.

In Schottarum, pollen is released through a subapical stomial pore from a short theca path. Endothecial cells surround the thecae paths. Pollen of S. sarikeense is a combination of a powdery mass and threads. The staggered release of pollen covered Colocasiomyia when these insects seemingly consume liquid from the pollen. The mode of thecae dehiscence and stamen structure, together with the liquid droplets as reward, may manipulate Colocasiomyia to perform its pollination duty to its host plant.

\section{Calcium oxalate packages}

Calcium oxalate packages are present in all three species investigated. In A. nicolsonii, the oxalate packages comprise octahedrons, while those of P. borneense and S. sarikeense are octahedrons and 3-D star-like crystals. A. nicolsonii produces the oxalate packages from within the horned thecae and also from stamen surfaces, but in $P$. borneense oxalate crystals are found on guard cells of stomata. Keating (2004) reports the presence of both types of oxalate package, raphides and crystal sand, in Aridarum borneense (M. Hotta) Bogner \& A. Hay. Barabé et al. (2004a) reports that in Schismatoglottis calyptrata, the oxalate packages are produced near stomata in the centre of the top portion of the stamen when the stamen and stigma are mature.

Oxalate crystals are found mixed with pollen at dehiscence in A. nicolsonii (prismatic crystals) and P. borneense (raphides: biforines). In P. borneense, the entire mass of biforines and pollen is ejected from the horned thecae. The occurrence of small and large calcium oxalate raphides attached to the pollen surface has been reported for representative taxa of eight genera in Schismatoglottideae (Barabé et al. 2004a,b; Ulrich et al. 2012). Interestingly, calcium oxalate crystals are found on Schismatoglottis but not in the small genera, apart from Hestia S.Y.Wong \& P.C.Boyce (Ulrich et al. 2012).

The role of calcium oxalate crystals has been the subject of speculation for many years, and is reviewed in Franceschi \& Horner (1980). Calcium oxalate crystals may, among other roles, give protection against insects and foraging animals, contribute to the strength of tissue, store calcium, bind toxic oxalate or be involved in surrounding degrading tissue. Presence of oxalate crystals with pollen is suggested to play a defensive role against consumption by pollinators, in pollen liberation or as a visual signal to insect visitors (Chase \& Peacor 1987;
D’Arcy et al. 1996; Coté \& Gibernau 2012). We found some support for the role of oxalate crystals as protection against herbivory as in all the species observed the staminate zone (and pistillate zone) is not damaged by the chrysomelids. However, there was heavy predation in some inflorescences of A. nicolsonii. Often, predating activity of chrysomelids started just before the onset of pistillate anthesis, and by the time the inflorescence reached staminate anthesis the spadix had been seriously damaged.

\section{Fruit set and protection to developing infructescences}

Reproductive success was evident several days after anthesis as visible enlargement of ovaries. Fructification rate among the three taxa investigated was high, at $>90 \%$. This is significantly higher than results for Furtadoa sumatrensis (40-50\%), a rheophytic taxon also pollinated by Colocasiomyia (Mori \& Okada 2001). Our work with Homalomena shows similar high fruit set, at $>80 \%$ (Y. C. Hoe, personal communication). In a related taxon in the Neotropics, Philodendron acutatum Schott, also showed reproductive success of $>90 \%$ (Maia et al. 2010). Gottsberger \& Amaral (1984) considered the pollinator specificity observed in upland Atlantic Forest populations of Philodendron bipinnatifidum Schott ex Endl. as an effective strategy to increase reproductive success. Relying on a specialised pollen vector can significantly decrease the risk of interspecific pollen flow, and improve the rate of successful visitation, since visitors very probably carry only conspecific pollen (Faegri \& van der Pijl 1979).

In many unisexual-flowered aroids the role of protecting the developing infructescences is assumed either by the entire spathe or by the persistent lower spathe. Fruit exposure is variously enabled, mostly by the spathe splitting open (e.g. Alocasia (Schott) G.Don, Dieffenbachia Schott) or abscising from the base (e.g. Homalomena, Philodendron; Mayo et al. 1997). Infructescence development in many rheophytic Schismatoglottideae is unusual in that the developing fruits sit exposed in a cup-shaped persistent lower spathe, which later functions as a splash-cup from which seeds are ejected by the impact of water droplets. The infructescence of $A$. nicolsonii is open and fruits harden throughout the development stage. The mucilaginous layer seen post pistillate anthesis in A. nicolsonii is probably for protection. The layer is probably derived from breakdown of glandular stigmatic cells and of the transmitting tissue of the stylar canal and placental region, as observed for the monsteroids (Eyde et al. 1967). Knoll (1926) suggested that in Arum nigrum Schott the mucilaginous layer plays a role both in the germination of pollen and in nourishing insect pollinators while they are trapped within the spathe. The seeds of $A$. nicolsonii are embedded in a hard brittle matrix in the mature fruit, but during natural degradation of the fruit prior to ejection from the splash-cup it absorbs water and swells into a slimy or gelatinous pulp. The infructescences of $P$. borneense are protected by the lower spathe with a constricted orifice. The seeds are large and curved, with a micropylar appendage. In S. sarikeense the expanded pistillodes on the interstice protect the developing infructescence until decay prior to fruit maturity; seeds are small without a micropylar appendage. All the species have seeds with little or no endosperm. The cotyledonar hyperphyll functions as a storage organ and perhaps has a very limited haustorial role when endosperm is present. The 
cotyledonar sheath, hypocotyl and primary root tend to be reduced or often completely absent. All three species are water dispersed. Micropylar appendages split and spread to attach the seeds to rock surfaces for A. nicolsonii. In P. borneense, the micropylar appendage hooked itself onto the surface. The micropylar appendages fix the seed to the substrate, preventing it from being swept away by torrential water.

\section{CONCLUSIONS}

In this paper, we provide the first comprehensive study of flowering mechanisms and pollination strategies in Schismatoglottideae in their natural habitat. Depending on species, anthesis starts either at dawn or dusk and lasts for 26-29 h. Insect visitors are mostly attracted to the floral odour released at the onset of pistillate anthesis. Pollinators are identified as species of Colocasiomyia. Important floral characteristics for Colocasiomyia pollinations are a chamber for concentration of floral odour and restricted access for other insect visitors to the pistillate zone during pistillate anthesis. Horned thecae force pollen extrusion but the structure and mechanisms of the horns differ in A. nicolsonii and P. borneense. Calcium oxalate packages are present on the epidermis of stamens and protrude together with pollen for protection. The mechanism of micropylar appendages in seed germination varies in A. nicolsonii and $P$. borneense.

\section{ACKNOWLEDGEMENTS}

This study was partially funded by the ITTO fellowship [No. 056/10A] to the first author. This is part of on-going research funded by the Ministry of Education Malaysia through Vote No. ERGS/01(02)/808/2011(03), FRGS/STWN10(01)985/2013 (26) and NRGS/1089/2013-(03). The collaboration and support of the Sarawak Forestry Department is gratefully acknowledged. Most recent fieldwork and research was under Research Permit No. NCCD.907.4.4(Jld.9)-69 and Park Permit No. 140/ 2013. The first author is grateful to Heidi Halbritter, Martini Weber, Maria Von Balthazar, Silvia Ulrich, Anke Bellaire, Susanne Sontag, Perica Brodaric and Andrea Frosch-Radivo for guidance and technical support. We sincerely thank Masanori J. Toda, Haruo Matsuzawa, Alexander G. Kirejtshuk and Martin Fikáček for identifying the insect specimens. We are grateful to David Bröderbauer for valuable comments on the manuscript.

\section{SUPPORTING INFORMATION}

Additional Supporting Information may be found in the online version of this article:

Table S1. Scanning conditions of X-ray tomography.

Video S1. Rotating, virtual 3-D model of the staminate flower of Aridarum nicolsonii Bogner.

Video S2. Pollination observations of Phymatarum borneense M.Hotta at Mulu National Park, Sarawak, Malaysia.

Video S3. Rotating, virtual 3-D model of the staminate flower of Phymatarum borneense M.Hotta.

Video S4. Rotating, virtual 3-D model of the staminate flower of Schottarum borneense P.C.Boyce \& S.Y.Wong.

Appendix S1. Taxonomic position, herbarium voucher number and collection locality of the species used in this study.

\section{REFERENCES}

Barabé D., Lacroix C. (2001) Aspects of floral development in Philodendron grandifolium and P. megalophyllum (Araceae). International Journal of Plant Sciences, 162, 47-57.

Barabé D., Lacroix C., Bruneau A., Archambault A., Gibernau M. (2004a) Floral development and phylogenetic position of Schismatoglottis (Araceae). International Journal of Plant Sciences, 165, 173-189.

Barabé D., Lacroix C., Chouteau M., Gibernau M. (2004b) On the presence of extracellular calcium oxalate crystals on the inflorescences of Araceae. Botanical Journal of the Linnean Society, 146, 181190.

Bernhardt P. (1996) Anther adaptation in animal pollination. In: D’Arcy W.G., Keating R.C. (Eds), The anther: form, function and phylogeny. Cambridge University Press, Cambridge, UK, pp 192-220.

Bogner J., Hay A. (2000) Schismatoglottideae (Araceae) in Malesia 2: Aridarum, Bucephalandra, Phymatarum and Piptospatha. Telopea, 9, 179-222.

Boyce P.C., Wong S.Y. (2007) Studies on Schismatoglottideae (Araceae) of Borneo IV: preliminary observations of spathe senescence mechanics in Schismatoglottis Zoll. \& Moritzi in Sarawak, Malaysian Borneo. Aroideana, 30, 56-70.

Boyce P.C., Wong S.Y. (2008) Studies on Schismatoglottideae (Araceae) of Borneo VII: Schottarum and Bakoa, two new genera from Sarawak, Malaysian Borneo. Botanical Studies, 49, 393-404.

Boyce P.C., Wong S.Y. (2009) Schottariella mirifica P.C.Boyce \& S.Y.Wong: a new name for Schottarum sarikeense (Araceae: Schismatoglottideae) - an erratum. Botanical Studies, 50, 269-271.

Boyce P.C., Wong S.Y. (2013) Studies on Schismatoglottideae (Araceae) of Borneo XXVII - New species of Aridarum, and notes on the Aridarum Rostratum Complex. Willdenowia, 43, 91-99.

Bröderbauer D., Diaz A., Weber A. (2012) Reconstructing the origin and elaboration of insect-trapping inflorescences in the Araceae. American Journal of Botany, 99, 1666-1679.

Bröderbauer D., Ulrich S., Weber A. (2014) Adaptations for insect trapping in brood-site pollinated Colocasia (Araceae). Plant Biology, 16, 659-668.

Chase M.W., Peacor D.R. (1987) Crystal of calcium oxalate hydrate on perianth of Stelis Sw. Lindleyana, 2, 91-94.

Coté G.G., Gibernau M. (2012) Distribution of calcium oxalate crystals in floral organs of Araceae in relation to pollination strategy. American Journal of Botany, 99, 1231-1242.

Dalitzsch M. (1886) Beiträge zur Kenntnis der Blattanatomie der Araceen. Botanisches Centralblatt, 25, 153-156, 184-187, 217-219, 249-253, 280-285, 312318, 343-349, Taf. 3.

D'Arcy W.G., Keating R.C., Buchmann S.L. (1996) The calcium oxalate package or so-called resorption tissue in some angiosperm anthers. In: D'Arcy W.G., Keating R.C. (Eds), The anther: form, function and phylogeny. Cambridge University Press, Cambridge, UK, pp 159-190.

De Bary A. (1884) Comparative Anatomy of Vegetative Organs of the Phanerogams and Ferns. Clarendon Press, Oxford, UK, p 659.
Dötterl S., David A., Boland W., Silberbauer-Gottsberger I., Gottsberger G. (2012) Evidence for behavioral attractiveness of methoxylated aromatics in a dynastid scarab beetle-pollinated Araceae. Journal of Chemical Ecology, 38, 1539-1543.

Eyde R.H., Nicolson D.H., Sherwin P. (1967) A survey of floral anatomy in Araceae. American Journal of Botany, 54, 478-497.

Faegri K., van der Pijl L. (1979) The Principles of Pollination Ecology (3rd revised Edition). Pergamon Press, Oxford, UK, p 244.

Fartyal R.S., Gao J.-J., Toda M.J., Hu Y.-G., Takenaka Takano K., Suwito A., Katoh T., Takigahira T., Yin J.-T. (2013) Colocasiomyia (Diptera: Dosophilidae) revised phylogenetically, with a new species group having peculiar lifecycles on monsteroid (Araceae) host plants. Systematic Entomology, 38, 763-782.

Franceschi V.R., Horner H.T. (1980) Calcium oxalate crystals in plants. Botanical Review, 46, 361-427.

García P.E., Schönswetter P., Aguilar J.F., Feliner G.N., Schneeweiss G.M. (2009) Five molecular markers reveal extensive morphological homoplasy and reticulate evolution in the Malva alliance (Malvaceae). Molecular Phylogenetics and Evolution, 50, 226-239.

Gibernau M., Barabé D., Cerdan P., Dejean A. (1999) Beetle pollination of Philodendron solimoesense (Araceae) in French Guiana. International Journal of Plant Sciences, 160, 1135-1143.

Givnish T.J., Evans T.M., Pires J.C., Sytsma K.J. (1999) Polyphyly and convergent morphological evolution in Commelinales and Commelinidae: evidence from rbcL sequence data. Molecular Phylogenetics and Evolution, 12, 360-385. 
Gottsberger G., Amaral A. (1984) Pollination strategies in Brazilian Philodendron species. Berichte der Deutschen botanischen Gesellschaft, 97, 391-410.

Grayum M.H. (1984) Palynology and phylogeny of the Araceae. Ph.D. Thesis, University of Massachusetts, Amherst, USA: 852 pp.

Grayum M.H. (1992) Comparative external pollen ultrastructure of the Araceae and putatively related taxa. Monographs in Systematic Botany of the Missouri Botanical Gardens, 43, 1-167.

Hadacek F., Weber M. (2002) Club-shaped organs as additional osmophores within the Sauromatum inflorescence: odour analysis, ultrastructural changes and pollination aspects. Plant Biology, 4, 367-383.

Hoe Y.C., Wong S.Y., Boyce P.C., Wong M.H., Chan M.K.Y. (2011) Studies on Homalomeneae (Araceae) of Borneo VII: Homalomena debilicrista, a new species from Malaysian Borneo, and observations of its pollination mechanics. Plant Diversity and Evolution, 129, 77-87.

Kakishima S., Terajima Y., Murata J., Tsukaya H. (2011) Infrared thermography and odour composition of the Amorphophallus gigas (Araceae) inflorescence: the cooling effect of the odorous liquid. Plant Biology, 13, 502-507.

Keating R.C. (2004) Systematic occurrence of raphide crystals in Araceae. Annals of the Missouri Botanical Garden, 91, 495-504.

Kite G.C. (1995) The floral odour of Arum maculatum. Biochemical Systematics and Ecology, 23, 343-354.

Knoll F. (1926) Die Arum-Blütenstände und ihre Besucher (Insekten und Blumen IV). Abhandlungen der Zoologisch-Botanischen Gesellschaft in Wien, 12, 379-481.

Kumano Y., Yamaoka R. (2006) Synchronization between temporal variation in heat generation, floral scents and pollinator arrival in the beetle-pollinated tropical Araceae, Homalomena propinqua. Plant Species Biology, 21, 173-183.

Kumano-Nomura Y., Yamaoka R. (2009) Beetle visitations and associations with quantitative variation of attractants in floral odors of Homalomena propinqua (Araceae). Journal of Plant Research, 122, 183-192.

Low S.L., Wong S.Y., Boyce P.C. (2014) Schottarum (Schismatoglottideae: Araceae) substantiated based on combined nuclear and plastid DNA sequences. Plant Systematics and Evolution, 300, 607-617.

Maia A.C.D., Schlindwein C. (2006) Caladium bicolor (Araceae) and Cyclocephata celata (Coleoptera, Dynastinae): a well-established pollination system in the northern Atlantic Rainforest of Pernambuco, Brazil. Plant Biology, 8, 529-534.
Maia A.C.D., Schlindwein C., Navarro D., Gibernau M. (2010) Pollination of Philodendron acutatum (Araceae) in the Atlantic forest of northeastern Brazil: a single scarab beetle species guarantees high fruit set. International Journal of Plant Sciences, 171, 740-748.

Maia A.C.D., Dötterl S., Kaiser R., Silberbauer-Gottsberger I., Teichert H., Gibernau M., Navarro D.M.A.F., Schlindwein C., Gottsberger G. (2012) The key role of 4-methyl-5-vinylthiazole in the attraction of scarab beetle pollinators: a unique olfactory floral signal shared by Annonaceae and Araceae. Journal of Chemical Ecology, 38, 1072-1080.

Maia A.C.D., Gibernau M., Dötterl S., Navarro D.M.A.F., Seifert K., Müller T., Schlindwein C. (2013) The floral scent of Taccarum ulei (Araceae): attraction of scarab beetle pollinators to an unusual aliphatic acyloin. Phytochemistry, 93, 71-78.

Mayo S.J., Bogner J., Boyce P.C. (1997) The Genera of Araceae. Royal Botanic Gardens Kew, London, UK, p 370 .

Miyake T., Yafuso M. (2003) Floral scents affect reproductive success in fly-pollinated Alocasia odora (Araceae). American Journal of Botany, 90, 370-376.

Miyake T., Yafuso M. (2005) Pollination of Alocasia cucullata (Araceae) by two Colocasiomyia flies known to be specific pollinators for Alocasia odora. Plant Species Biology, 20, 201-208.

Mori Y., Okada H. (2001) Reproductive biology and pollen flow of a rheophytic aroid, Furtadoa sumatrensis (Araceae) in the Malesian wet tropics. Plant Systematics and Evolution, 227, 37-47.

Nauheimer L., Boyce P.C., Renner S.S. (2012) Giant taro and its relatives: a phylogeny of the large genus Alocasia (Araceae) sheds light on Miocene floristic exchange in the Malesian region. Molecular Phylogenetics and Evolution, 63, 43-51.

Patt J.M., French J.C., Schal C., Lech J., Hartman T.G. (1995) The pollination biology of Tuckahoe, Peltandra virginica (Araceae). American Journal of Botany, 82, 1230-1240.

Saether O.A. (1977) Female genitalia in Chironomidae and other Nematocera: morphology, phylogenies, keys. Bulletin of the Fisheries Research Board of Canada, 197, 1-210.

Scharaschkin T., Doyle J.A. (2006) Character evolution in Anaxagorea (Annonaceae). American Journal of Botany, 93, 36-54.

Solereder H., Meyer F.J. (1928) Systematische Anatomie der Monokotyledonen, Heft 3: Principes-SynanthaeSpathiflorae. Gebrüder Borntraeger, Berlin, Germany, pp 100-169.
Staedler Y.M., Masson D., Schönenberger J. (2013) Plant tissues in $3 \mathrm{D}$ via $\mathrm{X}$-ray tomography: simple contrasting methods allow high resolution imaging. PLoS ONE, 8, e75295.

Takenaka K., Yin J.T., Wen S.Y., Toda M.J. (2006) Pollination mutualism between a new species of the genus Colocasiomyia de Meijere (Diptera: Drosophilidae) and Steudnera colocasiifolia (Araceae) in Yunnan, China. Entomological Science, 9, 79-91.

Takenaka-Takano K., Repin R., Mohamed M.D., Toda M.J. (2012) Pollination mutualism between Alocasia macrorrhizos (Araceae) and two taxonomically undescribed Colocasiomyia species (Diptera: Drosophilidae) in Sabah, Borneo. Plant Biology, 14, 555-564.

Tung L.S., Wong S.Y., Boyce P.C. (2010) Studies on Homalomeneae (Araceae) of Borneo VI: Homalomena giamensis, a new species from Sarawak, Malaysian Borneo, with notes on its pollination. Aroideana, 33, 201-211.

Ulrich S., Hesse M., Bröderbauer D., Wong S.Y., Boyce P.C. (2012) Schismatoglottis and Apoballis (Araceae: Schismatoglottideae): a new example for the significance of pollen morphology in Araceae systematics. Taxon, 61, 281-292.

Vogel S., Martens J. (2000) A survey of the function of the lethal kettle traps of Arisaema (Araceae), with records of pollinating fungus gnats from Nepal. Botanical Journal of the Linnean Society, 133, 61-100. Wong S.Y. (2013) Rheophytism in Bornean Schismatoglottideae (Araceae). Systematic Botany, 38, 32-45.

Wong S.Y., Boyce P.C. (2007) Studies on Schismatoglottideae (Araceae) of Borneo II: Aridarum crassum, a new species from Sarawak, Malaysian Borneo. Gardens' Bulletin Singapore, 58, 279-286.

Wong S.Y., Boyce P.C. (2010) Studies on Schismatoglottideae (Araceae) of Borneo X. Pichinia, a new genus from Sarawak, Malaysian Borneo. Gardens' Bulletin Singapore, 61, 541-548.

Wong S.Y., Boyce P.C. (2013) The role of the interstice staminodes of Bucephalandra Schott (Araceae: Schismatoglottideae). The IAS Newsletter, 35, 11-12.

Wong S.Y., Boyce P.C., Ahmad Sofiman O., Leaw C.P. (2010) Molecular phylogeny of tribe Schismatoglottideae based on two plastid markers and recognition of a new tribe, Philonotieae, from the neotropics. Taxon, 59, 117-124.

Wong S.Y., Boyce P.C., Low S.L. (2012) Studies on Schismatoglottis (Araceae) of Borneo XXIV - two new species of Aridarum from Kalimantan, and notes on the Aridarum Burttii Complex. Willdenowia, 42, 261-268. 